\title{
Fur-rubbing with Piper leaves in the San Martín titi monkey, Callicebus oenanthe
}

\author{
Rosario Huashuayo-Llamocca ${ }^{1,2}$ and Eckhard W. Heymann ${ }^{3}$ \\ ${ }^{1}$ Proyecto Mono Tocón, Jr. Reyes Guerra No. 430, Moyobamba, Peru \\ ${ }^{2}$ Facultad de Ciencias Biológicas, Universidad Nacional San Luis Gonzaga de Ica, Av. Los Maestros s/n, Ica, \\ Peru \\ ${ }^{3}$ Verhaltensökologie und Soziobiologie, Deutsches Primatenzentrum, Leibniz-Institut für Primatenforschung, \\ Kellnerweg 4, 37077 Göttingen, Germany \\ Correspondence to: Eckhard W. Heymann (eheyman@gwdg.de)
}

Received: 21 April 2017 - Revised: 29 May 2017 - Accepted: 30 May 2017 - Published: 26 June 2017

\begin{abstract}
We report observations on fur-rubbing with leaves from Piper aduncum by a San Martín titi monkey, Callicebus oenanthe. Fur-rubbing occurred during the transition from the dry to the rainy season in a titi monkey group living in a forest fragment in the Moyobamba region of Peru. Since Piper leaves include very potent compounds that may affect ectoparasites, we tentatively interpret the observed fur-rubbing as self-medication.
\end{abstract}

\section{Introduction}

Several primate and at least one carnivore species rub their fur with arthropods or their secretions, plant material (leaves, resin) or other substances, including man-made substances (tobacco smoke, soap), both in the wild and in captivity (Birkinshaw, 1999; Bowler et al., 2015; Gasco et al., 2016; Gompper and Hoylman, 1993; Huffman, 1997, 2011; Morrogh-Bernard, 2009; Nolte, 1958). Repelling or killing ectoparasites and microbial pathogens is invoked as the principal function of fur-rubbing (Baker, 1996; Falótico et al., 2007; Valderrama et al., 2000; Weldon et al., 2003), but it may also be involved in social bonding and olfactory communication (Campbell, 2000; Leca et al., 2007; Paukner and Suomi, 2012).

For titi monkeys, Carrillo-Bilbao et al. (2005) report furrubbing with chewed leaves of Tetrathylacium in Callicebus discolor (Plecturocebus discolor) from Yasuní, Ecuador, and with chewed leaves of five Annonaceae species and one Bignonaceae species in Callicebus toppini (Plecturocebus toppini) from Manu, Peru. In this paper, we report the use of Piper aduncum leaves by the San Martín titi monkey Callicebus oenanthe (Plecturocebus oenanthe), observed during an ecological study on this endemic and highly endangered species.

\section{Methods}

\subsection{Study area}

The observations were made in a 4 ha forest fragment surrounded by pastures and agricultural fields in the district of Yantaló, province of Moyobamba, department of San Martín (UTM coordinates: 9338221.4 northing, 274918.8 easting, 18M; Fig. 1). The fragment is located at the periphery of the protected area "Morro de Calzada". The vegetation is dominated by species of Vochysiaceae, Moraceae, Lauraceae and Bignonaceae. It reaches $12-15 \mathrm{~m}$ height and includes a dense understory (Romero Herrada, unpublished data). Average annual temperature is $22.8^{\circ} \mathrm{C}$ and annual precipitation around $1350 \mathrm{~mm}$ with $<100 \mathrm{~mm}$ per month from May to August (climate-data.org, 2017). During our study period, September also received $<100 \mathrm{~mm}$ rain (Fig. 2).

\subsection{Study group and observational methods}

The study group included one adult male, one adult female, one subadult female and one juvenile female. It was observed between May and December 2014, for a total of $238 \mathrm{~h}$. We used instantaneous scan sampling for determining the activity budget and use of space, focal animal sampling for feed- 


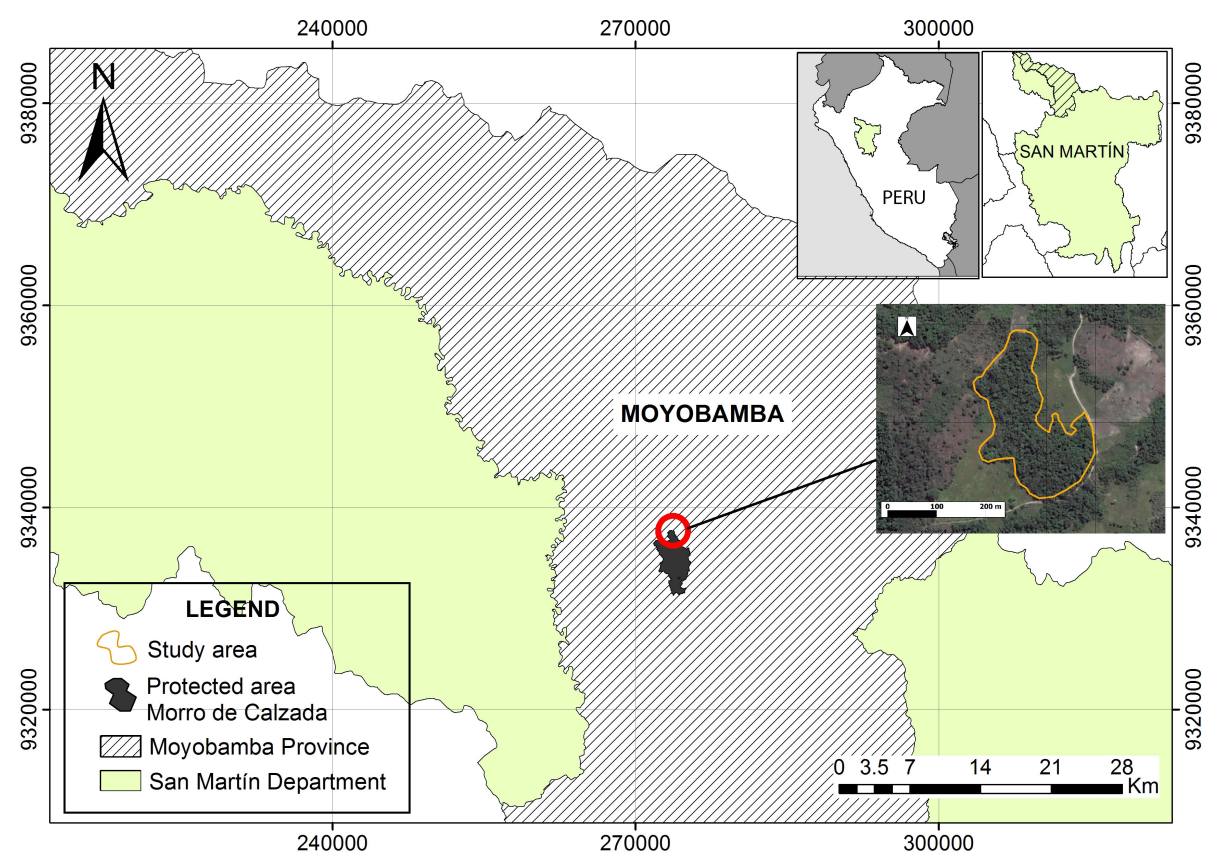

Figure 1. Location of the study area.

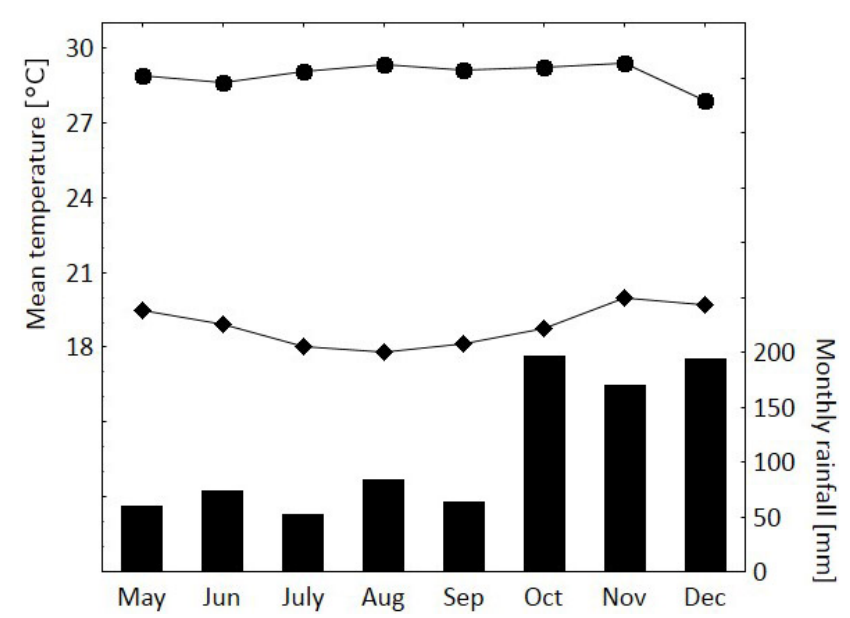

Figure 2. Mean daily maximum temperature (•), mean daily minimum temperature $(\bullet)$ and total monthly rainfall (bars) during the study period May-December 2014. Data from http://www.senamhi. gob.pe/main_mapa.php?t=dHi (accessed 5 April 2017).

ing behaviour and behaviour sampling (for rare but significant behaviours like the one reported here).

\section{Results}

During focal animal observations, the adult male was seen three times in September and October biting off a leaf from spiked pepper trees, Piper aduncum, and squeezing it with both hands. Then the squeezed leaf was rubbed against the abdominal area. This behaviour lasted between 5 and 15 min and involved either a single leaf or up to four leaves.

The adult female was also observed rubbing the abdominal area, but we never saw the collection of $P$. aduncum leaves. We could not see whether the female may have used material smaller than $P$. aduncum leaves for fur-rubbing. Fur-rubbing was not observed in the subadult and juvenile females.

\section{Discussion}

Piper aduncum, known in Peru as "matico", is widely distributed in the Neotropics. It is used in traditional medicine for a broad spectrum of ailments. This includes both internal and external (topical) use of leaf extracts, infusions and decoctions (Taylor, 2006). Constituents of $P$. aduncum, like dillapiole and other phenylpropanoids, are potent insecticides (Fazolin et al., 2014; Marques and Kaplan, 2015; Pino et al., 2011; Piton et al., 2014; Ribeiro et al., 2016; Vila et al., 2005; Volpe et al., 2015). Extracts of P. aduncum have also been shown to possess antifungal properties (Santos et al., 2013). While it is unclear whether extracts obtained by squeezing the leaves render all these bioactive constituents, it is highly likely that at least some constituents are released. Therefore, it is plausible to assume that the fur-rubbing with $P$. aduncum leaves observed in $C$. oenanthe functions as a topical selfmedication, as suggested for several other primate species. Wild capuchin monkeys, Cebus capucinus, and captive owl monkeys, Aotus spp., have been reported to use leaves from Piper marginatum for fur-rubbing (Baker, 1996; Zito et al., 2003). 
Fur-rubbing was observed in September and October, which are months that mark the fast transition from the relatively dry to the wet season (Fig. 2). We speculate that it is related to repelling or killing ectoparasites like ticks, chiggers or mosquitoes that might increase with the onset of the rainy season. For instance, the tick Amblyomma longirostre that infests a large number of birds, and terrestrial and arboreal mammals (mainly rodents) throughout the Neotropics, is known from the Moyobamba region (Nava et al., 2010). Alouatta guariba and Sapajus nigritus are infested by different species of Amblyomma (Guglielmone et al., 1990; Martins et al., 2015), and larval Amblyomma were the most common ectoparasite of Leontopithecus rosalia (Wilson et al., 1989). As ticks have several life stages (larvae, nymphs, adults), their response to climatic conditions can be quite complex, but some species may show higher activity of adults during the rainy season (Labruna et al., 2002; Lacerra de Souza et al., 2006). In sifakas, Propithecus edwardsi, ectoparasite richness was higher in the wet compared to the dry season in all habitats, as was the intensity of tick and fly infestations in disturbed habitats (Wright et al., 2009). Mouse lemurs, Microcebus griseorufus, were infested by ticks during the dry season, and males have higher infestation rates than females due to more frequent use of the ground (Rodriguez et al., 2015). Infestation by chiggers also varies seasonally (e.g. Dietsch, 2005), and mosquitoes are more abundant during the rainy season.

Although our observations are anecdotal and information on ectoparasites in the Moyobamba region is scanty, our report expands the number of primate species that exhibit topical application of leaves with medical potential.

Data availability. There are no further data apart from the observations reported in the paper.

Competing interests. Eckhard W. Heymann and Dietmar Zinner are employed by different departments of the Deutsches Primatenzentrum.

Acknowledgements. We are grateful to Alberto A. Guglielmone (Instituto Nacional de Tecnología Agropecuaria, Rafaela, Argentina) for help with literature on ticks and to Jaemy Romero Herrada for botanical identification of the leaves and for sharing his unpublished data on habitat characterization and structure in the protected area Morro de Calzada. We are thankful to Michael Huffman, Dietmar Zinner and an anonymous reviewer for constructive comments on the manuscript. The study during which the observations were made was conducted under authorization from the Dirección General Forestal y de Fauna Silvestre of the Ministerio de Agricultura in Lima (authorization no. 0208-2012AG-DGFFS-DGEFFS) and was only possible due to financial support from Le Conservatoire pour la Protection, La Vallée des Singes Primate Park, Blackpool Zoo, Zoo Amnéville, Paris Zoo,
London Zoo, Zoo de la Boissière du Doré, Apenheul Primate Park and Basel Zoo to the Proyecto Mono Tocón. We are most grateful to these institutions.

Edited by: Dietmar Zinner

Reviewed by: Michael Huffman and one anonymous referee

\section{References}

Baker, M.: Fur rubbing: use of medicinal plants by capuchin monkeys (Cebus capucinus), Am. J. Primatol., 38, 263-270, 1996.

Birkinshaw, C. R.: Use of millipedes by black lemurs to anoint their bodies, Folia Primatol., 70, 170-181, 1999.

Bowler, M., Messer, E. J. E., Claidière, N., and Whiten, A.: Mutual medication in capuchin monkeys - Social anointing improves coverage of topically applied anti-parasite medicines, Scientific Reports, 5, 15030, https://doi.org/10.1038/srep15030, 2015.

Campbell, C. J.: Fur rubbing behavior in free-ranging black-handed spider monkeys (Ateles geoffroyi) in Panama, Am. J. Primatol., 51, 205-208, 2000.

Carrillo-Bilbao, G., Di Fiore, A., and Fernandez-Duque, E.: Dieta, forrajeo y presupuesto de tiempo en cotoncillos (Callicebus discolor) del Parque Nacional Yasuní en la Amazonia ecuatoriana, Neotro. Primates, 13, 7-11, 2005.

Climate-data.org: Climate: Moyobamba, available at: https://en. climate-data.org/location/4364/, last access: 29 May 2017.

Dietsch, T. V.: Seasonal variation of infestation by ectoparasitic chigger mite larvae (Acarina: Trombiculidae) on resident and migratory birds in coffee agroecosystems of Chiapas, Mexico, J. Parasitol., 91, 1294-1303, 2005.

Falótico, T., Labruna, M. B., Verderane, M. P., De Resende, B. D., Izar, P., and Ottoni, E. B.: Repellent efficacy of formic acid and the abdominal secretion of carpenter ants (Hymenoptera: Formicidae) against Amblyomma ticks (Acari: Ixodidae), J. Med. Entomol., 44, 718-721, 2007.

Gasco, A. D. C., Pérez-Acosta, A. M., and Monticelli, P. F.: Ring-tailed coatis anointing with soap: a new variation of selfmedication culture?, Int. J. Comp. Psychol., 29, 1-11, 2016.

Gompper, M. E. and Hoylman, A. M.: Grooming with Trattinnickia resin: possible pharmaceutical plant use by coatis, J. Trop. Ecol., 9, 533-540, 1993.

Guglielmone, A. A., Mangold, A. J., and Keirans, J. E.: Redescription of the male and female of Amblyomma parvum Aragao, 1908, and description of the nymph and larva, and description of all stages of Amblyomma pseudoparvum sp. n. (Acari: Ixodida: Ixodidae), Acarologia, 31, 143-159, 1990.

Huffman, M. A.: Current evidence for self-medication in primates: a multidisciplinary perspective, Yearb. Phys. Anthropol., 40, 171200, 1997.

Huffman, M. A.: Primate self-medication, in: Primates in perspective, 2nd edn., edited by: Campbell, C., Fuentes, A., MacKinnon, K., Panger, M., and Bearder S., University of Oxford Press, Oxford, 563-573, 2011.

Labruna, M. B., Kasai, N., Ferreira, F., Faccini, J. L. H., and Gennari, S. M.: Seasonal dynamics of ticks (Acari: Ixodidae) on horses in the state of São Paulo, Brazil, Vet. Parasitol., 105, 6577, 2002.

Lacerra de Souza, S. S. A., de Souza, C. E., Neto, E. J. R., and do Prado, A. P.: Dinâmica sazonal de carrapatos (Acari: Ixodi- 
dae) na mata ciliar de uma área endêmica para febre maculosa na região de Campinas, São Paulo, Brasil, Ciencia Rural, 36, 887891, 2006.

Leca, J.-B., Gunst, N., and Petit, O.: Social aspects of fur-rubbing in Cebus capucinus and C. apella, Int. J. Primatol., 28, 801-817, 2007.

Marques, A. and Kaplan, M. A. C.: Active metabolites of the genus Piper against Aedes aegypti: natural alternative sources for dengue vector control, Universitas Scientiarum, 20, 61-82, 2015.

Martins, T. F., Teixeira, R. H. F., and Labruna, M. B.: Ocorrência de carrapatos em animais silvestres recebidos e atendidos pelo Parque Zoológico Municipal Quinzinho de Barros, Sorocaba, São Paulo, Brasil, Braz. J. Vet. Res. Anim. Sci., 52, 319-324, 2015.

Morrogh-Bernard, H. C.: Fur-rubbing as a form of self-medication in Pongo pygmaeus, Int. J. Primatol., 29, 1059-1064, 2009.

Nava, S., Velazco, P. M., and Guglielmone, A. A.: First record of Amblyomma longirostre (Koch, 1844) (Acari: Ixodidae) from Peru, with a review of this tick's host relationships, Syst. Appl. Acarol., 15, 21-30, 2010.

Nolte, A.: Beobachtungen über das Instinktverhalten von Kapuzineraffen (Cebus apella L.) in der Gefangenschaft, Behaviour, 12, 183-207, 1958.

Paukner, A. and Suomi, S. J.: Social after-effects of fur rubbing in tufted capuchin monkeys (Cebus apella): increased antagonism and reduced affiliation, Primates, 53, 297-301, 2012.

Pino, O., Sánchez, Y., Rodríguez, H., Correa, T., Demedio, J., and Sanabria, J.: Chemical characterization and acaricidal activity of the essential oil from Piper aduncum subsp. ossanum against Varroa destructor, Revista de Protección Vegetal, 26, 52-61, 2011.

Piton, L. P., Turchen, L. M., Butnariu, A. R., and Pereira, M. J. B.: Natural insecticide based-leaves extract of Piper aduncum (Piperaceae) in the control of stink bug brown soybean, Ciência Rural, 44, 1915-1920, 2014.

Ribeiro, N., Camara, C., and Ramos, C.: Toxicity of essential oils of Piper marginatum Jacq. against Tetranychus urticae Koch and Neoseiulus californicus (McGregor), Chilean Journal of Agricultural Research, 76, 71-76, 2016.

Rodriguez, I. A., Rasoazanabary, E., and Godfrey, L. R.: Seasonal variation in the abundance and distribution of ticks that parasitize Microcebus griseorufus at the Bezà Mahafaly Special Reserve, Madagascar, I. J. Parasitol., 4, 408-413, 2015.
Santos, M. L., Magalhães, C. F., Rosa, M. B. d., Santos, D. d. A., Brasileiro, B. G., Carvalho, L. M. d., Silva, M. B. d., Zani, C. L., Siqueira, E. P. d., and Peres, R. L.: Antifungal activity of extracts from Piper aduncum leaves prepared by different solvents and extraction techniques against dermatophytes Trichophyton rubrum and Trichophyton interdigitale, Brazil. J. Microbiol., 44, 1275-1278, 2013.

Taylor, L.: Technical data report for matico (Piper aduncum, angustifolium), available at: http://www.rain-tree.com/reports/ matico-tech-report.pdf (last access: 30 November 2016), 2006.

Valderrama, X., Robinson, J. G., Attygalle, A. B., and Eisner, T.: Seasonal anointment with millipedes in a wild primate: a chemical defense against insects?, J. Chem. Ecol., 26, 2781-2790, 2000.

Vila, R., Tomi, F., Mundina, M., Santana, A. I., Solís, P. N., Lopez Arce, J. B., Iclina, B., José, L., Iglesias, J., and Gupta, M. P.: Unusual composition of the essential oils from the leaves of Piper aduncum, Flavour Frag. J., 20, 67-69, 2005.

Volpe, H. X., Fazolin, M., Garcia, R. B., Magnani, R. F., Barbosa, J. C., and Miranda, M. P.: Efficacy of essential oil of Piper aduncum against nymphs and adults of Diaphorina citri, Pest Manageg. Sci., 76, 1242-1249, https://doi.org/10.1002/ps.4143, 2015.

Weldon, P. J., Aldrich, J. R., Klun, J. A., Oliver, J. E., and Debboun, M.: Benzoquinones from millipedes deter mosquitoes and elicit self-anointing in capuchin monkeys (Cebus spp.), Naturwissenschaften, 90, 301-304, 2003.

Wilson, N., Dietz, J. M., and Whitaker Jr., J. O.: Ectoparasitic Acari found on golden lion tamarins (Leontopithecus rosalia rosalia) from Brazil, J. Wildlife Dis., 25, 433-435, 1989.

Wright, P. C., Arrigo-Nelson, S. J., Hogg, K. L., Bannon, B., Morelli, T. L., Wyatt, J., Harivelo, A. L., and Ratelolahy, F.: Habitat disturbance and seasonal fluctuations of lemur parasites in the rain forest of Ranomafana National Park, Madagascar, in: Primate parasite ecology: the dynamics and study of hostparasite relationships, edited by: Huffman, M. A. and Chapman, C. A., Cambridge University Press, Cambridge, 311-330, 2009.

Zito, M., Evans, S., and Weldon, P. J.: Owl monkeys (Aotus spp.) self-anoint with plants and millipedes, Folia Primatol., 74, 159$161,2003$. 